\title{
Analisis Persediaan Produk Gula Rafinasi Menggunakan Metode Economic Production Quantity
}

\author{
Edo Rantou Wijaya ${ }^{1}$, Titania ${ }^{1}$ \\ ${ }^{1}$ Politeknik ATI Padang, Jl. Bungo Pasang Tabing, Padang, 25171, Indonesia
}

\section{ARTICLE INFORMATION}

Received: May 26, 2021

Revised: June 14, 2021

Available online: June 30, 2021

\section{KEYWORDS}

Economic Production Quantity, Optimal

Solution, Total Inventory Cost, Sensitivity

Analysis

\section{CORRESPONDENCE}

Name: Edo Rantou Wijaya

E-mail: edorantou@kemenperin.go.id

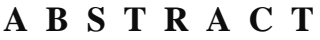

Overload is a condition where the goods stored in the warehouse exceed the existing capacity. With the accumulation, it will increase the storage cost for the products/goods stored. The purpose of this research was to help companies determine the optimal amount of production, optimal production time intervals and maximum product inventory so that there is no excess stock of products in the warehouse, and to obtain a minimum total inventory cost by using the Economic Production Quantity (EPQ) model. To collect the data needed in this study, secondary data was used which consists of production data and product delivery of company X. From the research results, the optimal production rate $\left(\mathrm{Q}^{*}\right)$ is $13,646 \mathrm{MT} /$ production cycle with an optimal production time interval of 1.16 months. or equal to 35 days, the maximum amount of inventory (Imax) was 429 MT. The total minimum inventory cost in one production cycle/month is Rp.167,925,698.28, -. The difference in total inventory costs generated using the EPQ method and calculations based on company conditions is $9 \%$ or equivalent to Rp.16,538,501, -. Based on the results of the sensitivity analysis it was known that all parameters are sensitive to $Q^{*}$, Imax, and total inventory costs. However, a significant change is the parameter of saving costs, where the increase and decrease in saving costs will decrease and increase $Q^{*}, \operatorname{Imax}$, and the total cost of inventory.
\end{abstract}

\section{PENDAHULUAN}

Setiap perusahaan, baik itu perusahan jasa maupun perusahaan manufaktur selalu memerlukan persediaan. Tanpa adanya persediaan, para pengusaha akan dihadapkan pada resiko bahwa perusahaan pada suatu waktu tidak dapat memenuhi keinginan pelanggan. Dalam sistem manufaktur, persediaan merupakan bagian penting dari perusahaan. Perusahaan memproduksi barang sesuai pesanan konsumen, dalam rincian perencanaan produksinya telah ditentukan terlebih dahulu oleh konsumen. Namun bagi perusahaan yang memproduksi barang untuk persediaan harus memperhitungkan tingkat persediaan yang ada dan perkiraan penjualan dari setiap produk yang dihasilkan. Apabila terjadi kesalahan dalam menentukan jumlah produksi maka akan mengakibatkan produksi yang kurang atau berlebih sehingga menimbulkan pemborosan atau DOI: http://dx.doi.org/10.52759/inventory.v2i1.33 menumpuknya persediaan [1-4]. Pengendalian persediaan merupakan fungsi manajerial yang sangat penting, karena sebagian besar perusahaan melibatkan investasi besar dalam aspek ini (20\% sampai 60\%). Jika perusahaan menyimpan terlalu banyak persediaan, maka menyebabkan biaya penyimpanan yang berlebihan, sedangkan jika perusahaan tidak memiliki persediaan yang cukup, biaya pengadaan darurat akan lebih mahal. Mengingat konsekuensi logis dari dilema (kekurangan atau kelebihan) persediaan, perusahaan harus merencanakan dan mengendalikan persediaan pada tingkat yang optimal [5]. Jika perusahaan menyimpan terlalu banyak persediaan, maka menyebabkan biaya penyimpanan yang berlebihan, sedangkan jika perusahaan tidak memiliki persediaan yang cukup, biaya pengadaan darurat akan lebih mahal. Mengingat konsekuensi logis dari dilema (kekurangan atau kelebihan) persediaan, perusahaan harus merencanakan dan mengendalikan persediaan pada tingkat yang optimal [5].

Attribution-ShareAlike 4.0 International. 
PT. X merupakan perusahaan yang bergerak di bidang industri makanan yang memproduksi gula rafinasi. Perusahaan ini memasok produknya ke pasar makanan dan minuman lokal sebagai permintaan gula lokal tahunan. Di gudang produk jadi, perusahaan $\mathrm{X}$ sering mengalami penumpukan produk sehingga gudang menjadi kelebihan beban. Overload adalah suatu kondisi dimana barang yang disimpan di gudang melebihi kapasitas yang ada. Dengan build-up, itu akan meningkatkan biaya penyimpanan untuk produk. Penelitian ini dilakukan dalam pengendalian persediaan untuk membantu perusahaan menentukan jumlah produksi yang optimal, interval waktu produksi yang optimal dan persediaan produk yang maksimal sehingga tidak terjadi kelebihan stok produk di gudang, dan untuk mendapatkan total biaya persediaan yang minimum. Setelah mendapatkan solusi optimum dari perhitungan menggunakan metode Economic Production Quantity (EOQ), selanjutnya dilakukan pengujian sensitivitas. Uji sensitivitas ini digunakan untuk mengetahui apakah perubahan parameter akan mempengaruhi solusi optimum perhitungan menggunakan metode EPQ yaitu $\mathrm{Q}^{*}$, Imax dan TC EPQ.

Model Economic Production Quantity (EPQ) merupakan lanjutan dari EOQ dimana model tersebut membutuhkan dua parameter tambahan yaitu tingkat permintaan harian (d) dan tingkat produksi harian (p), dengan tingkat produksi harian lebih besar dari permintaan harian ( $p>d)$ [1-4]. Salah satu asumsi dalam model persediaan EPQ adalah jumlah produksi lebih besar dari jumlah yang diminta. Dalam dua penelitian sebelumnya, jumlah produksi tidak selalu melebihi permintaan sehingga pasokan yang terjadi di perusahaan berfluktuasi [2][4]. Pada satu waktu penawaran lebih dari permintaan dan di lain waktu kurang dari permintaan. Sedangkan dalam penelitian ini kondisi volume produksi perusahaan selalu melebihi permintaan memenuhi salah satu asumsi model persediaan EPQ. Economic Production Quantity atau model EPQ menentukan kuantitas produksi optimal yang harus diproduksi oleh produsen atau pemasok untuk meminimalkan total biaya produksi dan persediaan per unit produk dengan menyeimbangkan biaya produksi dan persediaan yang terkait [6]. Model EPQ merupakan perluasan yang mudah dari model EOQ, yang diterapkan pada lingkungan produksi, bukan pada lingkungan pengecer/distribusi [6].

\section{METODOLOGI}

Metodologi penelitian secara sederhana dapat disajikan dalam bentuk flowchart penelitian. Flowchart penelitian menjelaskan bagaimana langkah-langkah yang dilakukan mulai dari awal penelitian sampai penelitian ini selesai dilakukan, yang dapat dilihat pada gambar 1 .

Pengolahan data diawali dengan pengujian normalitas data produksi yang dimiliki menggunakan uji normalitas Liliefors. Jika hasil uji normalitas menunjukkan bahwa data berdistribusi normal, maka dilanjutkan dengan perhitungan tingkat produksi optimal, interval waktu optimal, tingkat persediaan maksimum, dan total biaya persediaan optimal menggunakan EPQ inventory. model menggunakan parameter yang diketahui. Kemudian solusi optimal tersebut dibandingkan dengan solusi yang saat ini terjadi di perusahaan. Solusi yang optimal diharapkan dapat memberikan hasil yang lebih baik dari solusi yang diperoleh perusahaan saat ini. Jika variabel optimal diketahui, langkah selanjutnya adalah memverifikasi model EPQ menggunakan analisis sensitivitas. Dari hasil analisis sensitivitas dapat diketahui bahwa variabel-variabel yang sensitif terhadap perubahan parameter diketahui.

\section{Uji Normalitas Liliefors}

Pada uji normalitas Liliefors, terima $\mathrm{H}_{0}$ jika Lhitung $\mathrm{L}_{\text {tabel }}$ yang berarti data berdistribusi normal, tolak $\mathrm{H}_{0}$ jika $\mathrm{L}_{\text {hitung }}>\mathrm{L}_{\text {tabel }}$ yang menyatakan data tidak berdistribusi normal. Dalam melakukan pengujian normalitas data digunakan program SPSS. Dari pengujian menggunakan SPSS diperoleh tiga jenis output, yaitu: Processing Summary, Deskriptif, Tests of Normality, dan QQ Plots. Dengan SPPS, data dapat dikatakan normal $\left(\mathrm{H}_{0}\right.$ diterima) jika nilai signifikansi $\mathrm{K}_{\mathrm{S}}>$ taraf signifikan $=0,05$ [7].

\section{Metode Economic Production Quantity (EPQ)}

Economic Production Quantity atau Model Economic Production Quantity (EPQ) menentukan kuantitas produksi optimal yang harus diproduksi oleh produsen atau pemasok untuk meminimalkan total biaya produksi dan persediaan per unit produk dengan menyeimbangkan biaya produksi dan persediaan terkait. EPQ dikembangkan oleh Taft (1918), sebagai perpanjangan dari model kuantitas pesanan ekonomi (EOQ). Perbedaan antara kedua metode ini mendasari asumsi teoretis mereka. Model EPQ mengasumsikan perusahaan akan memproduksi kuantitasnya sendiri atau suku cadang dikirim ke perusahaan saat sedang diproduksi. Oleh karena itu, pesanan tersedia atau diterima secara bertahap saat produk sedang diproduksi. Di sisi lain, model EOQ mengasumsikan jumlah pesanan tiba sepenuhnya dan segera setelah pemesanan. Mirip dengan model EOQ, EPQ adalah lot produk tunggal dari metode penjadwalan [8]. Ada empat model 
matematika yang digunakan untuk melakukan perhitungan yaitu:

$\operatorname{EPQ}\left(Q^{*}\right)=\sqrt{\frac{2 D S}{H\left(1-\frac{d}{p}\right)}}$

$t_{0}=\frac{Q^{*}}{d}$

Persediaan maksimum

$\operatorname{IMax}=Q^{*}\left(1-\frac{d}{p}\right)$

Total biaya persediaan EPQ

$T C E P Q=\frac{D}{Q^{*}} S+\frac{I M a x}{2} H$

\section{Analisis Sensitivitas}

Analisis sensitivitas merupakan investigasi terhadap perubahan nilai parameter $\left(\mathrm{a}_{\mathrm{ij}}, \mathrm{b}_{\mathrm{i}}, \mathrm{c}_{\mathrm{j}}\right)$ yang berpengaruh pada penyelesaian optimal [9]. Analisis perubahan parameter dan pengaruhnya terhadap solusi optimal disebut analisis pasca optimalitas. Istilah pasca optimalitas menunjukkan bahwa analisis ini terjadi setelah solusi optimal diperoleh, dengan asumsi seperangkat nilai parameter yang digunakan dalam model [10] [11].

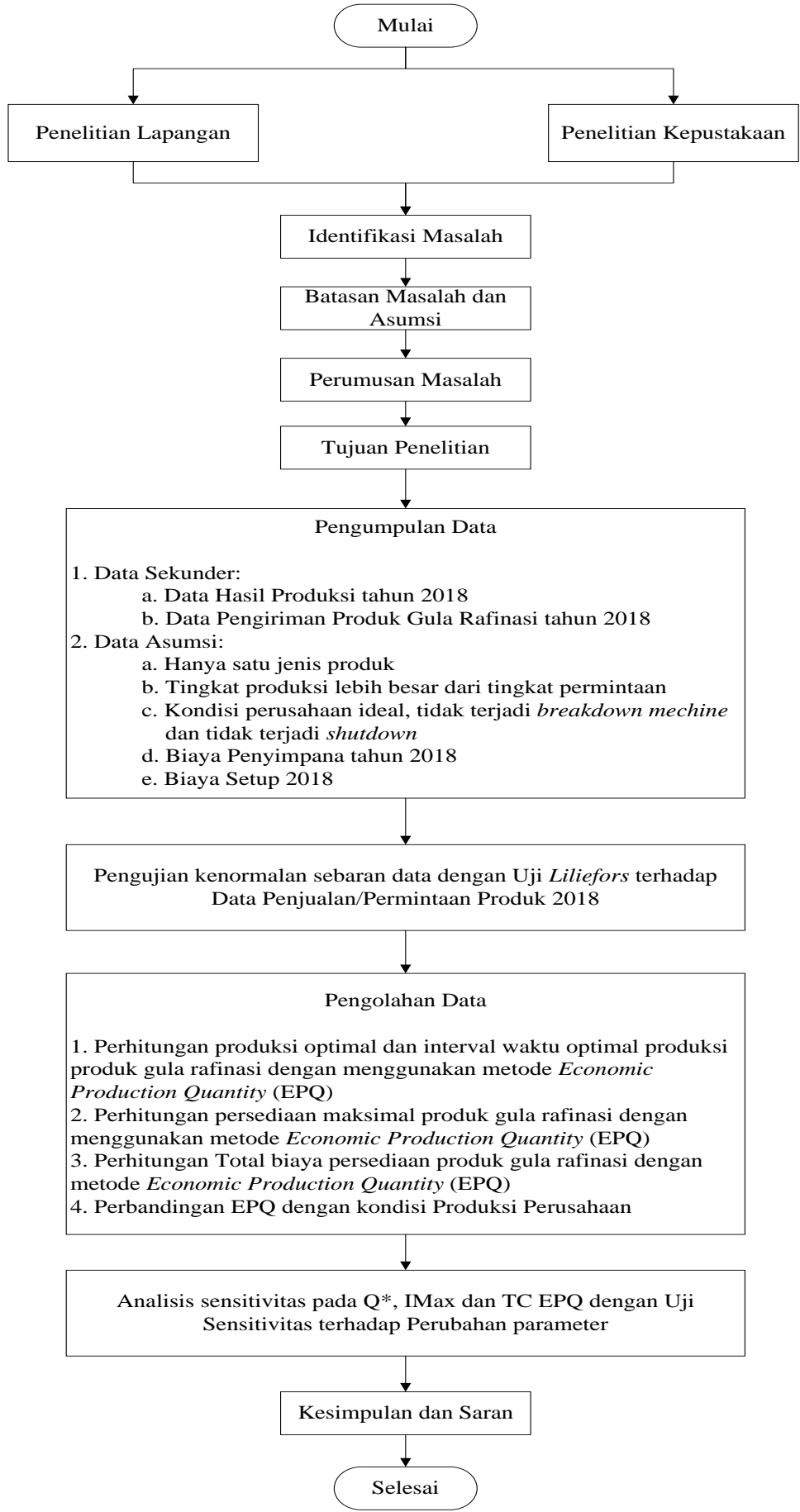

Gambar 1. Flowchart Penelitian 


\section{HASIL DAN PEMBAHASAN}

\section{Pengumpulan Data}

\section{Data Biaya Persediaan}

Dalam melakukan pengolahan data metode EPQ, dibutuhkan data biaya terkait persediaan. Pada PT. X biaya persediaan terdiri dari biaya penyimpanan dan biaya setup. Berikut ini disajikan tabel 1 berikut.

Tabel 1. Data Biaya Persediaan PT. X 2018

\begin{tabular}{ll}
\hline Jenis Biaya & \multicolumn{1}{c}{ Jumlah } \\
\hline Biaya Penyimpanan & Rp. 4.700.000,- /MT/tahun \\
Biaya Setup & Rp. 97.524.000,- /tahun \\
\hline (sumber: PT. $X$ 2018) &
\end{tabular}

\section{Data Produksi dan Permintaan Produk}

Dalam menghitung dengan metode EPQ, diperlukan data hasil produksi dan data penjualan (permintaan) terhadap produk PT. X. Data tersebut dapat dilihat pada tabel 1 dan tabel 2 berikut.

Tabel 2. Data Hasil Produksi 2018

\begin{tabular}{lr}
\hline \multicolumn{1}{c}{ FG } & Total (MT) \\
\hline Januari & 298.55 \\
Februari & 16185.10 \\
Maret & 16188.85 \\
April & 11409.25 \\
Mei & 16078.70 \\
Juni & 9254.25 \\
Juli & 18076.05 \\
Agustus & 18143.25 \\
September & 4645.35 \\
Oktober & 0.00 \\
November & 16298.40 \\
Desember & 6844.15 \\
Total (Tons) & 133421.90 \\
Total (Bags) & 2668438.00 \\
\hline
\end{tabular}

Pada tabel 2 merupakan data hasil produksi produk gula rafinasi pada tahun 2018. Dari tabel diatas dapat diketahui bahwa jumlah produk yang dihasilkan pada tahun 2018 adalah sebanyak 133.421.90 MT atau setara dengan 2.668.438 Bags (karung). Pada bulan Oktober 2018, tidak ada hasil produksi, maka dapat diketahui bahwa pada tahun 2018 perusahaan hanya melakukan produksi dalam 11 bulan.

Pada tabel 3 merupakan data pengiriman atau permintaan produk gula rafinasi kepada konsumen pada tahun 2018. Dari tabel diatas dapat diketahui bahwa jumlah produk yang dikirim pada tahun 2018 adalah sebanyak 140.977,95 MT atau setara dengan 2.819.558,90 Bags (karung).

Tabel 3. Data Pengiriman PT. X 2018

\begin{tabular}{lr}
\hline Delivery & Total (MT) \\
\hline Januari & 10998.00 \\
Februari & 8691.35 \\
Maret & 13198.65 \\
April & 11414.75 \\
Mei & 19096.55 \\
Juni & 10912.02 \\
Juli & 18064.98 \\
Agustus & 12830.60 \\
September & 11069.90 \\
Oktober & 8470.05 \\
November & 7260.50 \\
Desember & 8970.60 \\
Total (Tons) & $140,977.95$ \\
Total (Bags) & $2,819,558.90$ \\
\hline
\end{tabular}

\section{Pengolahan Data}

\section{Uji Normalitas Liliefors}

Untuk melihat kenormalan sebaran data permintaan gula rafinasi tahun 2018, maka dilakukan uji normalitas liliefors. Pada uji ini dibutuhkan data pengiriman atau permintaan produk yang dapat dilihat pada tabel 3 dan membutuhkan hipotesis serta kriteria pengujian.

Hipotesisnya adalah sebagai berikut:

H0: Data berdistribusi normal

H1: Data tidak berdistribusi normal

Kriteria pengujian:

H0 diterima jika sign kolmogorov smirnov $^{a}>$ dari tingkat signifikansi $\alpha=0.05$

H0 ditolak jika sign kolmogorov smirnov ${ }^{a}<$ dari tingkat signifikansi $\alpha=0.05$.

Dalam uji normalitas data dengan liliefors, dilakukan dengan menggunakan program aplikasi SPSS Statistics 17. Adapun hasil pengolahan dapat dilihat pada tabel 4 berikut:

Tabel 4. Test of Normality

\begin{tabular}{llllllll}
\hline \multicolumn{7}{c}{ Kolmogorov-Smirnov $^{\mathrm{a}}$} & \multicolumn{3}{c}{ Shapiro- } \\
Wilk \\
\hline Statistic & df & Sig. & Statistic & df & Sig. \\
Permintaan & .203 & 12 & .185 & .883 & 12 & .095 \\
a. Lilliefors Significance Correction \\
\hline
\end{tabular}

Dari tampilan tabel Test of Normality dapat dilihat bahwa nilai Kolmogorov-Smirnov ${ }^{a}$ sebesar 0.185. Nilai ini lebih besar dibandingkan dengan nilai tingkat signifikansi $\alpha=0.05$. Maka dari itu dapat disimpulkan 
bahwa hipotesis H0: data berdistribusi normal dan kriteria pengujian $\mathrm{H} 0$ dapat diterima karena nilai Sign. kolmogorov smirnov $v^{a}>\alpha=0.05$.

\section{Pengolahan Data menggunakan EPQ}

Jumlah Produksi Optimal dan Interval Waktu Optimal

Berdasarkan data-data yang telah ada maka dilakukan perhitungan untuk menentukan jumlah produksi optimal. Dari tabel 2 dan tabel 3 dapat dihitung antara lain:

Rata-rata jumlah produksi per bulan:

$p=\frac{\text { total produksi tahun } 2018}{11} \approx p=\frac{133421,9}{11}$
$\approx p=12129,26 \mathrm{MT} /$ bulan

Rata-rata jumlah pengiriman/permintaan per bulan:

$$
\begin{aligned}
d=\frac{\text { total pengiriman tahun } 2018}{12} \approx d \\
=\frac{140977,95}{12} \approx d \\
=11748,16 \text { MT } / \text { bulan }
\end{aligned}
$$

Biaya simpan:

$H=$ Rp. 4.700.000,-/MT pertahun

Biaya setup:

$S=$ Rp. 97.524.000,-/tahun

Untuk selanjutnya, dilakukan perhitungan $Q^{*}$ dengan menggunakan rumus pada persamaan

$$
\begin{aligned}
1 . E P Q & \left(Q^{*}\right)=\sqrt{\frac{2 D S}{H\left(1-\frac{d}{p}\right)}} \approx \operatorname{EPQ}\left(Q^{*}\right) \\
= & \sqrt{\frac{2(140977,95)(97524000)}{4700000\left(1-\frac{11748,16}{12129,26}\right.}} \approx 13645,65 \mathrm{MT}
\end{aligned}
$$

Maka diperoleh hasil tingkat produksi optimal dalam setiap putaran produksi adalah 13.645,65 MT atau 13.646 MT. Dalam hal ini, saat produksi telah mencapai titik optimal, produksi akan berhenti karna telah mencapai tingkat optimalnya dan persediaan akan berkurang selama periode putaran produksi. Maka dari itu, saat produksi terhenti perusahaan tidak shutdown tetapi perusahaan dapat melakukan maintenance pada mesin produksi dan tetap menjalankan operasional lainnya.

Setelah dilakukan perhitungan untuk mengetahui tingkat produksi optimal dalam setiap putaran produksi, langkah selanjutnya adalah menghitung interval waktu optimal $\left(t_{0}\right)$ menggunakan persamaan 2 :

$t_{0}=\frac{13646}{11748,16} \approx 1,16$
Dari perhitungan diatas diketahui interval waktu optimal untuk setiap putaran produksi adalah 1,16 bulan atau sama dengan 35 hari. Dari dua perhitungan diatas dapat diketahui jumlah produksi perputaran produksi adalah 13.646 MT/35 hari = $392 \mathrm{MT} /$ hari.

\section{Jumlah Persediaan Maksimal}

Untuk menghitung jumlah persediaan produk maksimal (IMax), dilakukan dengan menggunakan persamaan 3 . Adapun perhitungan untuk mengetahui jumlah persediaan produk maksimal adalah sebagai berikut:

$\operatorname{IMax}=13646\left(1-\frac{11748,16}{12129,26}\right) \approx 428,75$

Dari perhitungan diatas diketahui, jumlah persediaan maksimal produk adalah sebesar 429 MT setelah dibulatkan.

\section{Total Biaya Persediaan}

Berikutnya untuk menghitung total biaya persediaan, digunakan persamaan 4 .

$$
\begin{gathered}
\mathrm{TCEPQ}=\left(\frac{140977,95}{13646}(97524000)\right)+\left(\frac{428,75}{2}(4700000)\right) \\
\approx 167925698,28 / \text { bulan }
\end{gathered}
$$

Dari hasil perhitungan dengan metode EPQ dengan asumsi produk yang diproduksi hanya satu jenis produk, diperoleh biaya persediaan yang dikeluarkan perusahaan setiap periodenya adalah sebesar Rp. 2.015.108.379,34 atau setara dengan Rp.167.925.698,28,- per bulan. Sedangkan dari kondisi perusahaan terlebih dahulu menghitung nilai total persediaan maksimal dan kembali menghitung total biaya EPQ, yaitu:

$$
\begin{aligned}
\operatorname{IMax}=Q\left(1-\frac{d}{p}\right) & \approx \operatorname{IMax}=12129,26\left(1-\frac{11748,16}{12129,26}\right) \\
& \approx 381,1 \text { MT }
\end{aligned}
$$

Dari perhitungan diatas diketahui jumlah persediaan maksimal dengan kondisi perusahaan adalah 381,10 MT. Sehingga total biaya persediaan perusahaan dengan menggunakan persamaan 4 adalah sebagai berikut.

$$
\begin{aligned}
\text { TC perusahaan }= & \left(\frac{140977,95}{12129,26}(97524000)\right) \\
& +\left(\frac{381,1}{2}(4700000)\right) \\
& \approx 2029106192,01 / \text { periode }
\end{aligned}
$$

Total biaya persediaan yang dikeluarkan oleh perusahaan dalam periode 2018 dengan menggunakan data hasil produksi dan permintaan produk yang telah digabungkan menjadi satu produk adalah sebesar Rp.2.029.106.192,02 atau setara dengan Rp. 184.464.199,27/bulan. 
Tabel 5. Hasil Analisis Sensitivitas

\begin{tabular}{|c|c|c|c|c|c|}
\hline Parameter & Perubahan $(\%)$ & Hasil Perubahan & Q* (Perputaran Produksi) & IMAX & TC EPQ (Rp.) \\
\hline \multirow{11}{*}{$\mathrm{D}$} & 25 & 176,222 & 15,256 & 479 & $2,252,959,659$ \\
\hline & 20 & 169,174 & 14,948 & 470 & $2,207,440,630$ \\
\hline & 15 & 162,125 & 14,633 & 460 & $2,160,962,991$ \\
\hline & 10 & 155,076 & 14,312 & 450 & $2,113,463,498$ \\
\hline & 5 & 148,027 & 13,983 & 439 & $2,064,871,635$ \\
\hline & 0 & 140,978 & 13,646 & 429 & $2,015,180,379$ \\
\hline & -5 & 133,929 & 13,300 & 418 & $1,964,084,696$ \\
\hline & -10 & 126,880 & 12,945 & 407 & $1,911,699,663$ \\
\hline & -15 & 119,831 & 12,581 & 395 & $1,857,838,129$ \\
\hline & -20 & 112,782 & 12,205 & 383 & $1,802,367,727$ \\
\hline & -25 & 105,733 & $\mathbf{1 1 , 8 1 7}$ & 371 & $1,745,135,048$ \\
\hline \multirow{11}{*}{$\mathrm{S}$} & 25 & $121,905,000$ & 15,256 & 479 & $2,252,959,659$ \\
\hline & 20 & $117,028,800$ & 14,948 & 470 & $2,207,440,630$ \\
\hline & 15 & $112,152,600$ & 14,633 & 460 & $2,160,962,991$ \\
\hline & 10 & $107,400,200$ & 14,312 & 450 & $2,113,463,498$ \\
\hline & 5 & $102,400,200$ & 13,983 & 439 & $2,064,871,635$ \\
\hline & 0 & $97,524,000$ & 13,646 & 429 & $2,015,180,379$ \\
\hline & -5 & $92,647,800$ & 13,300 & 418 & $1,964,084,696$ \\
\hline & -10 & $87,771,600$ & 12,945 & 407 & $1,911,699,663$ \\
\hline & -15 & $82,895,400$ & 12,581 & 395 & $1,857,838,129$ \\
\hline & -20 & $78,019,200$ & 12,205 & 383 & $1,802,367,727$ \\
\hline & -25 & $73,143,200$ & 11,817 & 371 & $1,745,135,048$ \\
\hline \multirow{11}{*}{$\mathrm{H}$} & 25 & $5,875,000$ & 12,205 & 383 & $2,252,959,659$ \\
\hline & 20 & $5,640,000$ & 12,457 & 391 & $2,207,440,630$ \\
\hline & 15 & $5,405,000$ & 12,725 & 400 & $2,160,962,991$ \\
\hline & 10 & $5,170,000$ & 13,011 & 409 & $2,113,463,498$ \\
\hline & 5 & $4,935,000$ & 13,317 & 418 & $2,064,871,635$ \\
\hline & 0 & $4,700,000$ & 13,646 & 429 & $2,015,180,379$ \\
\hline & -5 & $4,465,000$ & 14,000 & 440 & $1,964,084,696$ \\
\hline & -10 & $4,230,000$ & 14,384 & 452 & $1,911,699,663$ \\
\hline & -15 & $3,995,000$ & 14,801 & 465 & $1,857,838,129$ \\
\hline & -20 & $3,760,000$ & 15,256 & 479 & $1,802,367,727$ \\
\hline & -25 & $3,525,000$ & 15,757 & 495 & $1,745,135,048$ \\
\hline \multirow{11}{*}{$\mathrm{d}$} & 25 & 14,685 & - & - & - \\
\hline & 20 & 14,09 & - & - & - \\
\hline & 15 & 13,510 & - & - & - \\
\hline & 10 & 12,923 & - & - & - \\
\hline & 5 & 12,336 & - & - & - \\
\hline & 0 & 11,748 & 13,646 & 429 & $2,015,108,379$ \\
\hline & -5 & 11,161 & 8,560 & 269 & $2,238,230,210$ \\
\hline & -10 & 10,573 & 6,753 & 212 & $2,534,478,935$ \\
\hline & -15 & 9,986 & 5,754 & 181 & $2,814,276,991$ \\
\hline & -20 & 9,399 & 5,098 & 160 & $3,073,441,787$ \\
\hline & -25 & 8,811 & 4,625 & 145 & $3,314,465,475$ \\
\hline \multirow{11}{*}{$\mathrm{P}$} & 25 & 15,162 & 5,098 & 160 & $3,073,441,787$ \\
\hline & 20 & 14,555 & 5,508 & 173 & $2,902,863,754$ \\
\hline & 15 & 13,949 & 6,090 & 191 & $2,707,315,500$ \\
\hline & 10 & 13,342 & 6,998 & 220 & $2,481,413,951$ \\
\hline & 5 & 12,736 & 8,686 & 273 & $2,224,195,166$ \\
\hline & 0 & 12,129 & 13,646 & 429 & $2,015,108,379$ \\
\hline & -5 & 11,523 & - & - & - \\
\hline & -10 & 10,916 & - & - & - \\
\hline & -15 & 10,310 & - & - & - \\
\hline & -20 & 9,703 & - & - & - \\
\hline & -25 & 9,097 & - & - & - \\
\hline
\end{tabular}

\section{Analisis Sensitivitas}

Dari hasil pengolahan menggunakan metode EPQ diperoleh hasil optimum yang dapat dilihat pada tabel 6 berikut:
Tabel 6. Solusi Optimum EPQ

\begin{tabular}{ccc}
\hline $\mathbf{Q}^{*}$ & Imax & TC EPQ \\
\hline 13.646 & 429 & $2,015,108,379.34$
\end{tabular}


Selanjutnya dilakukan analisis sensitivitas terhadap variabel keputusan $\mathrm{Q}^{*}$, Imax dan TC EPQ, ketika parameter yang dapat dilihat pada tabel 7 berubah sebesar $25 \%, 20 \%, 15 \%, 10 \%, 5 \%,-5 \%,-10 \%,-15 \%$, $20 \%$, dan $-25 \%$.

Tabel 7. Parameter

\begin{tabular}{ccccc}
\hline $\mathbf{D}$ & $\mathbf{S}$ & $\mathbf{H}$ & $\mathbf{d}$ & $\mathbf{p}$ \\
\hline $140,977.95$ & $975,534,000$ & $4,700,000$ & $11,748.16$ & $12,129.26$ \\
\hline
\end{tabular}

Dari Tabel 5 diketahui bahwa hasil analisis sensitivitas perubahan parameter sebesar 25\%, 20\%, 15\%, 10\%, $5 \%,-5 \%,-10 \%,-15 \%,-20 \%$, dan $-25 \%$ mempunyai pengaruh terhadap $\mathrm{Q}^{*}$, Imax dan TC EPQ.

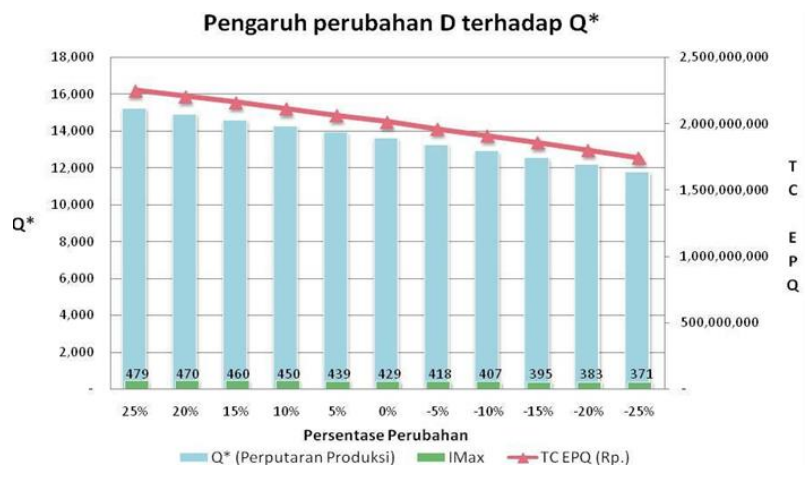

Gambar 2. Grafik Pengaruh Perubahan D terhadap Q*

Dari Gambar 2 diketahui bahwa makin besar permintaan tingkat produksi juga akan semakin besar maka makin besar pula jumlah persediaan maksimum dan total biaya persediaan. Hal ini berarti tingkat produksi optimal, jumlah persediaan maksimal dan total biaya persediaan sensitif terhadap perubahan jumlah permintaan pertahun.

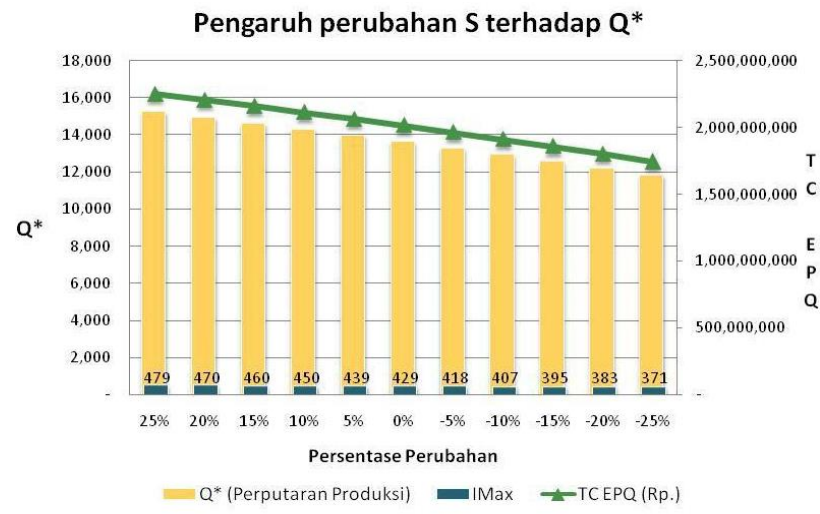

Gambar 3. Grafik Perubahan S terhadap Q*

Dari Gambar 3 diketahui bahwa makin besar biaya setup tingkat produksi juga akan semakin besar maka makin besar pula jumlah persediaan maksimum dan total biaya persediaan. Hal ini berarti tingkat produksi optimal, jumlah persediaan maksimal dan total biaya persediaan sensitif terhadap total biaya setup pertahun.

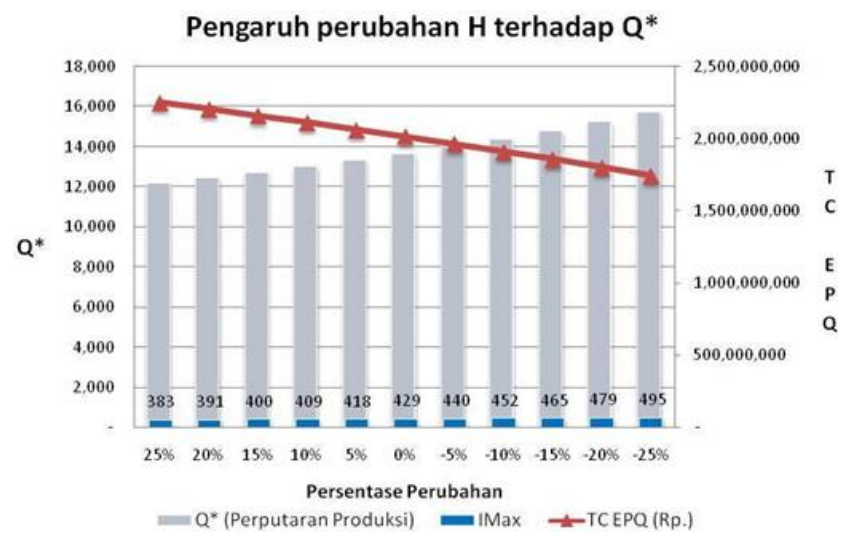

Gambar 4. Grafik Perubahan H terhadap Q*

Dari gambar 4 diketahui bahwa semakin besar biaya penyimpanan, tingkat produksi dan jumlah persediaan maksimal akan semakin berkurang dan total biaya persediaan akan semakin besar. Hal ini berarti saat biaya penyimpanan meningkat maka tingkat produksi dan persediaan maksimal diturunkan agar persediaan produk jadi dalam gudang tidak terlalu tinggi, sehingga dapat meminimumkan total biaya persediaan.

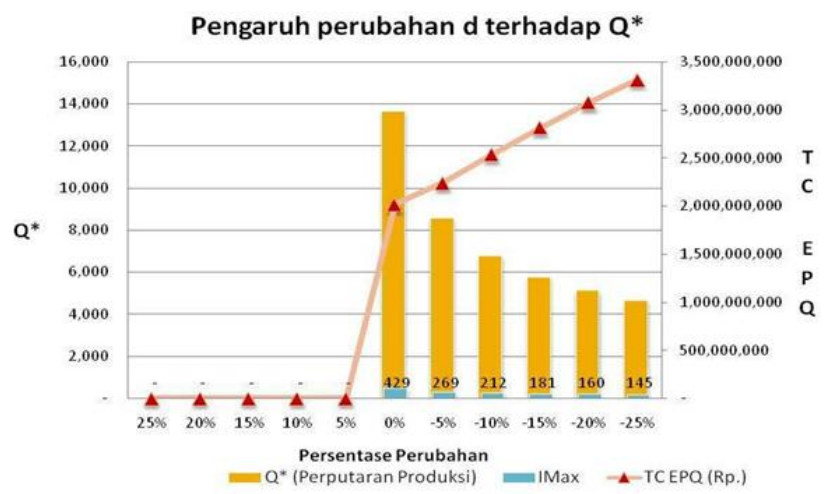

Gambar 5. Grafik Perubahan d terhadap Q*

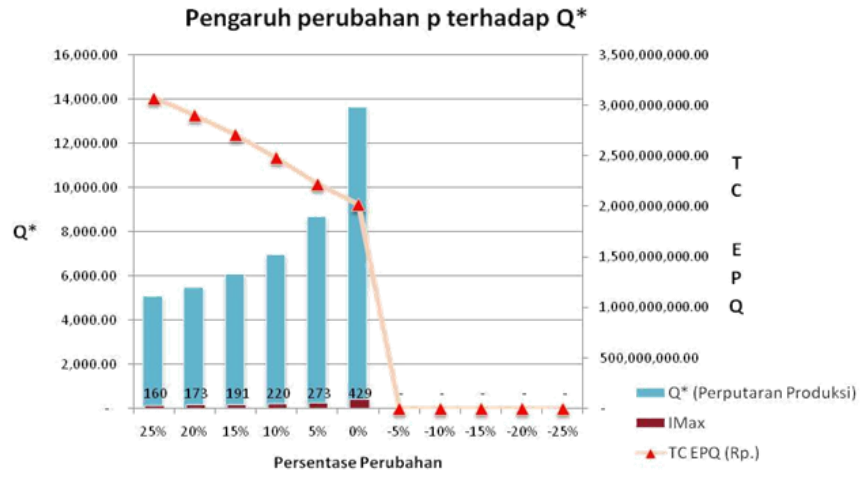

Gambar 6. Grafik Perubahan p terhadap Q*

Parameter selanjutnya yang dilakukan analisis sensitivitas adalah rata-rata permintaan per bulan (d) dan rata-rata produksi per bulan (p). Dari gambar 5 dan 6 dapat dilihat perubahan yang dapat diterima oleh parameter $d$ adalah penurunan sedangkan pada parameter $p$ adalah kenaikan. Hal ini dikarenakan dalam penerapan metode EPQ, tingkat produksi per bulan 
harus lebih besar dari tingkat permintaan per bulan $(p>d)$. Berdasarkan gambar 6 dapat diketahui makin kecil rata-rata permintaan per bulan, tingkat produksi dan jumlah persediaan maksimal akan semakin kecil. Hal ini berarti penurunan rata-rata permintaan sangat berpengaruh terhadap tingkat produksi dan jumlah persediaan maksimal. Pada analisis sensitivitas pengaruh perubahan rata-rata produksi per bulan, berdasarkan gambar 6 dapat diketahui, makin besar ratarata produksi per bulan, tingkat produksi dan jumlah persediaan maksimal akan semakin kecil. Hal ini berarti kenaikan rata-rata produksi sangat berpengaruh terhadap tingkat produksi dan jumlah persediaan maksimal.

\section{KESIMPULAN}

Berdasarkan hasil penelitian yang telah dilakukan terhadap penyediaan produk gula rafinasi PT. X tahun 2018 dapat disimpulkan beberapa hal. Pertama, data distribusi produk gula rafinasi pada tahun tersebut mengikuti pola distribusi normal. Kedua, Dari perhitungan data dengan menggunakan model Economic Production Quantity (EPQ), tingkat produksi optimal untuk produk gula rafinasi adalah 13.646 MT per siklus produksi dengan interval waktu optimal 1,16 bulan dengan tingkat produksi harian 392 MT. Sedangkan jumlah persediaan maksimum yang diperoleh adalah 429 MT. Ketiga, dari perhitungan total biaya persediaan dengan menggunakan model Economic Production Quantity (EPQ), total biaya persediaan adalah Rp. Rp. 167.925.698,28,- per bulan. Sedangkan jika dibandingkan dengan total biaya persediaan yang diterapkan perusahaan maka biaya yang dikeluarkan adalah sebesar Rp. 184.464.199,27/bulan. Dengan demikian perusahaan dapat menghemat biaya sebesar $9 \%$ atau setara dengan Rp. 16.538.501, -/bulan. Keempat, Dari hasil analisis sensitivitas parameter terlihat bahwa $\mathrm{Q}^{*}$, IMax dan TC EPQ sensitif terhadap semua parameter terutama parameter $\mathrm{d}$ dan $\mathrm{p}$.

\section{DAFTAR PUSTAKA}

[1] D. Tresna Ayu, "Analisis Pengedalian Tingkat Produksi Optimal Crumb Rubber Dengan Metode Economic Production Quantity (EPQ) (Studi Kasus: PT. Perkebunan Nusantara III Medan)," North Sumatera University, Medan, North Sumatera, Indonesi, 2018.

[2] N. P. F. Sayuni, A. Zukhri, and M. A. Meitriana, "Analisis Jumlah Produksi Optimal Dengan Metode Economic Production Quantity ( EPQ ) Pada Ud . Sinar Abadi Singaraja," vol. 00, no. 3, 2014.
[3] F. Putri, "Analisis Produksi Optimal Pengolahan Kopi Salak dengan Model Economic Production Quantity Pada UD. Salacca Padangsidimpuan," universitas sumatera utara, 2019.

[4] E. Fibriani, D. Cahyadi, and A. Farid H, "Model Economic Production Quantity (EPQ) dengan Sinkronisasi Demand Kontinu Dan Demand Diskrit pada Produksi Kerupuk Ikan Sungai Khas Kalimantan Timur," JST (Jurnal Sains Ter., vol. 4, no. 1, pp. 1-9, 2018, doi: 10.32487/jst.v4i1.444.

[5] J. E. Beigel, Perencanaan dan Pengendalian Produksi Cetakan Pertama. 1999.

[6] I. T. Christou, Quantitative methods in supply chain management: Models and algorithms, vol. 9780857297.2012.

[7] A. Narlan and D. T. Juniar, "Statistika dalam Penjas; Aplikasi praktis dalam penelitian pendidikan jasmani." p. 123, 2018, Accessed: Oct. 27, 2020. [Online]. Available: https://books.google.com/books?hl=en\&lr=\&id $=$ esKIDwAAQBAJ\&oi=fnd\&pg=PR5\&dq=Nar lan,+A.,+\%26+Juniar,+D.+T.+2018.+Statistika + Dalam+Penjas+Aplikasi+Praktis+Dalam+Pene litian+Pendidikan+Jasmani.+Yogyakarta:+Deep ublish\&ots $=$ YmFeB14ZH0\&sig $=r x N m o Z 21 U d$ AtN7EiEY502805T.

[8] S. E. S. Bariran, K. S. M. Sahari, and A. H. Mahlouji, "Developing a Heuristic Robotics Integrated Production Model for Economic Production Quantity in Mass Customization Manufacturing," in The Malaysia-Japan Model on Technology Partnership, Springer Japan, 2015, pp. 139-146.

[9] "Herjanto, E. 2006. Manajemen Operasi (Vol. Edisi... - Google Scholar." https://scholar.google.com/scholar?hl=en\&as_s $\mathrm{dt}=0 \% 2 \mathrm{C} 5 \& \mathrm{q}=$ Herjanto $\% 2 \mathrm{C}+\mathrm{E} .+2006 .+$ Manaj emen+Operasi+\%28Vol.+Edisi+Ketiga\%29.+Ja karta\%3A+Grasindo\&btnG $=($ accessed Oct. 27 , 2020).

[10] S. D. . Dewi, N. K. Tastrawati, and K. Sari, "Analisis Sensitivitas dalam Optimalisasi Keuntungan Produksi Busana dengan Metode Simpleks," J. Mat., vol. 4, no. 2, pp. 90-101, Dec. 2014, Accessed: Nov. 03, 2020. [Online]. Available: https://ocs.unud.ac.id/index.php/jmat/article/vie w/12553.

[11] R. U. Hurint, M. Z. Ndii, and M. Lobo, "Analisis Sensitivitas Model Epidemi SEIR," Nat. Sci. J. Sci. Technol., vol. 6, no. 1, pp. 2228, Mar. 2017, doi: 10.22487/25411969.2017.v6.i1.8076. 